NBER WORKING PAPER SERIES

\title{
THE IMPACT OF PRESUMED CONSENT LEGISLATION ON CADAVERIC ORGAN DONATION: A CROSS COUNTRY STUDY
}

\author{
Alberto Abadie \\ Sebastien Gay \\ Working Paper 10604 \\ http://www.nber.org/papers/w10604
NATIONAL BUREAU OF ECONOMIC RESEARCH 1050 Massachusetts Avenue
Cambridge, MA 02138
June 2004

We thank Susan Athey, Chris Avery, Adolfo de Motta, Mark Duggan, Michael Greenstone, Asim Khwaja, Nolan Miller, Balàzs Szentes, Richard Zeckhauser, and seminar participants at Harvard Economics for helpful comments and discussions. The views expressed herein are those of the author(s) and not necessarily those of the National Bureau of Economic Research.

(C)2004 by Alberto Abadie and Sebastien Gay. All rights reserved. Short sections of text, not to exceed two paragraphs, may be quoted without explicit permission provided that full credit, including (C notice, is given to the source. 
The Impact of Presumed Consent Legislation on Cadaveric Organ Donation:

A Cross Country Study

Alberto Abadie and Sebastien Gay

NBER Working Paper No. 10604

June 2004

JEL No. I18, J18

\title{
ABSTRACT
}

In the U.S., Great Britain, and in many other countries, the gap between the demand and the supply of human organs for transplantation is on the rise, despite the efforts of governments and health agencies to promote donor registration. In some countries of continental Europe, however, cadaveric organ procurement is based on the principle of presumed consent. Under presumed consent legislation, a deceased individual is classified as a potential donor in absence of explicit opposition to donation before death. This article analyzes the impact of presumed consent laws on donation rates. For this purpose, we construct a dataset on organ donation rates and potential factors affecting organ donation for 22 countries over a 10-year period. We find that while differences in other determinants of organ donation explain much of the variation in donation rates, after controlling for those determinants presumed consent legislation has a positive and sizeable effect on organ donation rates.

\author{
Alberto Abadie \\ John F. Kennedy School of Government \\ Harvard University \\ 79 JFK Street \\ Cambridge, MA 02138 \\ and NBER \\ alberto_abadie@harvard.edu \\ Sebastien Gay \\ Department of Economics \\ University of Chicago \\ 1126 East $59^{\text {th }}$ Street \\ Chicago, IL 60637 \\ sgay@uchicago.edu
}




\section{Introduction}

Chronic shortage of human organs for transplantation is one of the most pressing health policy issues in many developed countries, including the U.S. and Great Britain. In recent years, the persistent scarcity of organs for transplantation has invigorated the controversy about the determinants of organ donation rates and the magnitude of their effects. With a few exceptions, however, this debate has not been informed by systematic empirical studies. $^{1}$

A particularly heated debate has arisen on the matter of legislative defaults on cadaveric organ donation. In many countries, including the U.S., Great Britain, Germany and Australia, cadaveric organ procurement is carried out under the informed consent principle. Under an informed consent law, cadaveric organ extraction requires the explicit consent of the donor before death, which is usually reflected on a donor registration card. In contrast, in most of continental Europe, cadaveric organ procurement is based on the principle of presumed consent. Under presumed consent legislation, a deceased individual is classified as a potential donor in absence of explicit opposition to donation before death. In practice, regardless of the type of legislation and of whether a deceased individual is registered as a donor (or as a non-donor), in most countries families are allowed to have the last word on whether organs will be donated. It has been argued, however, that legislative defaults affect the decisions of potential donors and families. ${ }^{2}$

This article uses a panel of 22 countries over a 10-year period to analyze the impact of presumed consent laws on donation rates. After controlling for other determinants of cadaveric organ donation, we find that countries with presumed consent legislation have higher organ donation rates. Moreover, we use the panel structure of our database to test

\footnotetext{
${ }^{1}$ Notable exceptions are Gimbel et al. (2003) and Johnson and Goldstein (2003).

${ }^{2}$ See Sunstein and Thaler (2003).
} 
and reject the hypothesis that unmeasured (additive) determinants of organ donation rates confound our empirical results.

The rest of the article is organized as follows. Section II summarizes the main facts highlighted in the previous literature on organ donation. Section III presents a simple model that illustrates a way in which legislative defaults may affect organ donation rates. The main empirical results of the article are given in section IV. Section V concludes. Data sources and technical details are reported in the appendices.

\section{The Organ Shortage Problem}

In $2002,6,679$ patients died on the U.S. organ waiting lists before an organ became available, roughly 18 per day (OPTN, 2003). In spite of media campaigns and other attempts to promote donation, the supply of organs cannot keep up with the demand, and the number of patients on waiting lists has been growing steadily during the last decade (see Figure 1). One of the most frequently quoted explanations of the gap between the supply and demand of organs is that the number of families that refuse to grant consent to donation is still large. Approximately half of the families that are approached to request donation refuse it in the U.S. and Great Britain, compared to around 20\% in Spain and around $30 \%$ in France. ${ }^{3}$ The U.S. and Great Britain are informed consent countries; Spain and France are presumed consent countries.

From an economist's point of view, the shortage of cadaveric organs for transplantation is an intriguing phenomenon. First, from a purely utilitarian perspective, it represents the routine disposal of a highly valuable commodity, with the potential to save

\footnotetext{
${ }^{3}$ The figure for the U.S. comes from Nathan et al (2003) where it is taken from a variety of sources. For Great Britain, this information appears in Barber et al (2003), it refers to the period of April 2003 to June 2003, and it was conveyed to us in personal communication by Phil Pocock from UK Transplant. For Spain, we obtained the figure from ONT (2003) for the year 2002. Finally, for France, the figure comes from EFG (2003); it refers to the year 2002 and to potential donors deceased from encephalic death.
} 
lives. Moreover, survey data indicate a significant disagreement between preferences for donation and donor card registration. In particular, results from a well-known survey (Gallup, 1993) indicate that while most Americans favor organ donation (85\%), and would like to donate their organs after death $(69 \%)$, only a few grant permission for organ extraction on their driver's license or an organ donor card (28\%). Finally, in recent years the question of how defaults influence economic choices has become an issue of great interest among economists. ${ }^{4}$

The severe shortage of human organs for transplantation in the U.S. has prompted numerous proposals to alleviate this problem. In addition to presumed consent legislation, proposals include financial incentives for donors (Becker and Elias, 2003), xenotransplantation (transplantation of organs from a different species, usually pigs), educational campaigns, organ exchange mechanisms for living donors with incompatible recipients (Roth, Sonmez, and Unver, 2004), and preferential assignment of organs to registered donors. ${ }^{5}$

However, increasing donation consent rates from families is still viewed as the most promising route to increase organ donation (UNOS, 2002). Many analysts and health professionals believe that presumed consent legislation may play an important role in shaping the decision of the families. In an international survey of transplant professionals, $75 \%$ of the respondents supported presumed consent legislation, and $39 \%$ identified this type of legislation as the most effective measure to increase donation rates,

\footnotetext{
${ }^{4}$ In a very influential study, Madrian and Shea (2001) found that for workers at a certain large U.S. corporation the participation rate in the firm's $401(\mathrm{k})$ retirement plan was higher under default enrollment and many of the workers retained the default contribution rate and fund allocation. On the impact of defaults on economic behavior, see also Samuelson and Zeckhauser (1988), Choi et al (2003) and Thaler and Sunstein (2003).

${ }^{5} \mathrm{See} \mathrm{Oz}$ et al (2003). In addition, Votruba (2001) has studied the efficient allocation of cadaveric organs.
} 
the highest percentage among all measures considered in the survey, followed by improved education with $18 \%$ (Oz et al, 2003).

Several factors, beyond legislative defaults, have been hypothesized to affect cadaveric donation rates in the medical literature. These factors include the level of wealth, religious beliefs and social norms, education, and medical infrastructure. In addition, most deceased donors are patients who have suffered irreversible brain injury resulting in brain-death, but whose heartbeats are maintained through artificial ventilation. The most common causes of death of these patients are traffic accidents and cerebro-vascular diseases. Consequently, the mortality rates for these two causes of death have been considered important determinants of organ donation rates. ${ }^{6}$

In this article, we analyze the impact of presumed consent legislation on cadaveric organ donation, after controlling for other factors that affect organ donation rates. An important consideration regarding the analysis conducted here is that the content and enforcement of presumed consent laws vary greatly across countries. In Austria, for example, presumed consent legislation is applied rigorously, and deceased individuals are considered potential donors in absence of explicit opposition before death, regardless of the will of the family. In Spain, however, as in most presumed consent countries, even when organ removal can be carried-out by law without the consent of the family, organ coordinators in charge of the donation process do not authorize the extraction of organs without family approval.

Because registration is nominally free (in all countries to our knowledge) and because families are allowed to make the final decision on whether or not organs will be donated, it is not obvious that legislative defaults on cadaveric organ donation should

\footnotetext{
${ }^{6}$ See Cameron and Forsythe (2001) for a further discussion of the factors which determine organ donation rates.
} 
have an effect on donation rates. In the next section, we outline a simple model of donor registration and family consent that can sustain equilibria with higher donation rates in presumed consent countries than in informed consent countries.

\section{A Simple Model of Presumed Consent}

In this section, we outline a model of organ donation. Albeit simple, the model has two important implications: (1) even if families make the final decision on organ donation, presumed consent laws may result in notably higher consent and donation rates; (2) registration rates may be low even if registration costs are low (and even if preferences for donation are high in informed consent countries and low in presumed consent countries).

Let $u_{D}$ and $u_{N}$ be the utility levels realized in the donation and non-donation states, respectively. We allow $u_{D}$ and $u_{N}$ to vary across individuals. Let $v=u_{D}-u_{N}$ be the utility gain derived from donation. Individuals observe their own $v$ 's. Families, however, have imperfect information about the value of $v$ for family members. The information of families about $v$ is given by the mean-preserving spread $z=v+\varepsilon$, where $\varepsilon$ is independent of $v$ and has a log-concave density. ${ }^{7}$ The distributions of $v$ and $\varepsilon$ are common knowledge. Individuals pay "contemplation costs" equal to $c$ for registering as donors (in informed consent countries) or non-donors (in presumed consent countries). ${ }^{8,9}$ For simplicity, we assume $c$ to be fixed and known to everybody.

\footnotetext{
${ }^{7}$ Log-concavity is a non-parametric regularity condition often used in information economics. Logconcavity is satisfied by most common distributions, such as the normal, uniform, logistic, and Laplace distributions. See An (1998) for additional information on log-concavity.

${ }^{8}$ Arguably, it would be more appropriate to refer to $c$ as "registration costs" rather than "contemplation costs". However, we adopt the term "contemplation costs" in accordance with the medical literature, where the discrepancy between donation preferences and donor registration is habitually attributed to the perception that donor registration is often avoided because it forces potential donors to confront the prospect of their own death (see, e.g., AMA, 1994).
} 
This model can be represented as an extensive form game. First, individuals decide whether or not to register after observing $v$ and the type of legislation. Then, families decide whether or not to consent to donation, after observing the type of legislation, the registration decision of the individuals, and the value of $z$. Both potential donors and families choose their actions in order to maximize the expected utility of potential donors. Given the type of legislation, a pair of strategies in this game consists of two functions: the first function maps $v$ on the registration decision of potential donors; the second function maps $z$ and the registration decision of potential donors on the donation consent decisions of the families.

Equilibrium in an informed consent country. Consider a solution in which individuals register as donors if $v \in V_{I}$, with $v>0$ for all $v \in V_{I}$. Families do not override the decision of deceased potential donors because, conditional on registration, $v>0 .{ }^{10}$ For deceased potential donors who did not register, families evaluate $E\left[v \mid v \notin V_{I}, v+\varepsilon=z\right]$. Log-concavity of $\varepsilon$ and independence between $v$ and $\varepsilon$ guarantee that $v$ and $z$ are affiliated random variables. ${ }^{11}$ By the properties of affiliated random variables $E\left[v \mid v \notin V_{I}, v+\varepsilon=z\right]$ is a non-decreasing function of $z$. Therefore, there exists some $z_{I}$ such that families of non-registered potential donors comply with the informed consent

\footnotetext{
${ }^{9}$ In this model, registration can be regarded as a costly signaling device of donation preferences from the individual to the family. Instead of (or in addition to) signing a donor card, some individuals may communicate their preferences regarding organ donation directly to their relatives before death. However, survey data have detected a widespread reluctance to discuss organ donation issues with family members (see, for example, Gallup, 1993). Given that organ donor cards lack legal status and/or are not enforced in most countries, we conjecture that the role that organ donor cards may play in practice is to provide a channel to signal donation preferences to family members and organ procurement agencies, that does not require engaging in an active discussion with family members about death and organ donation preferences. See also Bryne and Thompson (2001) on the use of registration as a signal.

${ }^{10}$ In reality, families' own views on organ donation may sometimes influence consent decisions. However, it has been documented that families who know that their relatives wished to donate their organs after death overwhelmingly consent to donation (see Siminoff et al, 2001.)

${ }^{11}$ See Appendix A for the proof, and Krishna (2002) for more on affiliated random variables.
} 
default if $z \leq z_{I}$. For simplicity of the exposition, we will assume that $z_{I}$ is an interior point in the support of $z$.

Consequently, the expected utility of a non-registered potential donor in an informed consent country is $u_{N} \operatorname{Pr}\left(z \leq z_{I} \mid v\right)+u_{D} \operatorname{Pr}\left(z>z_{I} \mid v\right)$. The expected utility of a registered donor in an informed consent country is $u_{D}-c$. Therefore, an individual becomes a registered donor if $v \operatorname{Pr}\left(z \leq z_{I} \mid v\right)>c$, which is consistent with the assumption that all the elements of $V_{I}$ are positive. Notice that registered donors are a subset of those individuals with $v>c$.

An equilibrium is characterized in this model by

$$
V_{I}=\left\{v: v \operatorname{Pr}\left(z \leq z_{I} \mid v\right)>c\right\}
$$

for the registration decision of the individuals, and

$$
E\left[v \mid v \operatorname{Pr}\left(z \leq z_{I} \mid v\right)<c, v+\varepsilon=z_{I}\right]=0,
$$

for the donation consent decision of the families. ${ }^{12}$

Equilibrium in a presumed consent country. Under a presumed consent default the analysis is analogous. Consider a solution in which individuals register as non-donors if $v \in V_{P}$, with $v<0$ for all $v \in V_{P}$. Families do not override the decision of deceased potential donors because, conditional on registration, $v<0$. For deceased potential donors who did not register, families evaluate $E\left[v \mid v \notin V_{P}, v+\varepsilon=z\right]$. Because this expectation is a monotonic function of $z$, there exists some $z_{P}$ such that families of non-

\footnotetext{
${ }^{12}$ The concept of equilibrium is Perfect Bayesian Equilibrium. For simplicity, assume that $\varepsilon$ has full support on the real line. Then, every information set is on the equilibrium path, and Bayes' Rule applies everywhere. Families update their beliefs using Bayes' Rule, and the actions of potential donors are optimal given families' strategies.
} 
registered potential donors comply with the presumed consent default if $z \geq z_{P}$. We will consider the case in which $z_{P}$ is an interior point in the support of $z$.

Using the same analysis as for the informed consent case, it is easy to show that an individual will register as a non-donor if $v \operatorname{Pr}\left(z \geq z_{P} \mid v\right)<-c$, which is consistent with the assumption that all the elements of $V_{P}$ are negative. Notice that registered non-donors are a subset of those individuals with $v<-c$.

A solution to this problem is given by

$$
V_{P}=\left\{v: v \operatorname{Pr}\left(z \geq z_{P} \mid v\right)<-c\right\},
$$

for the registration decision of the individuals, and

$$
E\left[v \mid v \operatorname{Pr}\left(z \geq z_{P} \mid v\right)>-c, v+\varepsilon=z_{P}\right]=0,
$$

for the donation consent decision of the families.

Implications of the model. It can be shown that if the density of $\varepsilon$ is log-concave, then, for any given $z_{I}$ and $z_{P}$, the sets $V_{I}$ and $V_{P}$ are either intervals or empty sets. ${ }^{13}$

Figure 2 shows an example of equilibrium strategies for the case when $V_{I}$ and $V_{P}$ are non-empty intervals in equilibrium. In an informed consent country, individuals register as donors if $v \in V_{I}$, and families consent to donation if either the deceased potential donor registered or if $z>z_{I}$. In a presumed consent country, individuals register as nondonors if $v \in V_{P}$, and families consent to donation if the deceased potential donor did not register and $z \geq z_{P}$.

Consider first the implications of the model under informed consent legislation. Because registration generates a contemplation cost, $c>0$, and because families have some information about $v$, not all individuals with $v>0$ register as donors. Individuals

\footnotetext{
${ }^{13}$ See Appendix A for the proof.
} 
with positive but low $v$ do not register because the contemplation cost is high relative to the utility derived from donation. Moreover, individuals with positive but low $v$ may not register even if $v>c$, provided that the probability that $z>z_{I}$ is large enough. Individuals with high $v$ may not register either, because the probability that for them $z \leq z_{I}$ is very small. Only individuals with intermediate positive values of $v$, those with $v \in V_{I}$, will register. ${ }^{14,15}$ In absence of registration costs, however, all the individuals with $v>0$ would register as donors. The combination of registration costs and the fact that families have additional information about the preferences for donation of family members reduces registration rates in informed consent countries. The same conclusion holds also for presumed consent countries.

A second important implication of the model is that legislative defaults on cadaveric organ donations may influence family consent rates for non-registered potential donors. Consider the setting in which both $\varepsilon$ and $v$ are symmetrically distributed with respect to zero. Then, it is easy to prove that $z_{P}=-z_{I}$ and $V_{P}=-V_{I}$. Using the fact that $z$ and $v$ are affiliated, it can be easily seen that $\operatorname{Pr}\left(z \geq z_{P} \mid v \notin V_{P}\right) \geq \operatorname{Pr}\left(z \geq z_{I} \mid v \notin V_{I}\right)$.

That is, under presumed consent, family consent rates for non-registered individuals are equal to or larger than under informed consent. At an intuitive level, informed consent laws allow individuals with strong preferences for donation to separate. As a result, families in informed consent countries infer that non-registered individuals had weak preferences for donation on average, and do not consent unless the indicator $z$ is large.

\footnotetext{
${ }^{14}$ In this sense, the model outlined in this section is related to some recent developments regarding nonmonotonic strategies in signaling models. See, e.g., Feltovich, Harbaugh, and To (2002).

${ }^{15}$ If the support of $v$ is bounded, all individuals with strong preferences for donation may register in equilibrium. That would be the case also if individuals with strong preferences for donation derived a sufficiently large consumption value from registration or if they incurred sufficiently lower contemplation costs. For simplicity and because the substantive implications of the model are identical, we do not follow these potential extensions here.
} 
In contrast, in presumed consent countries, individuals with strong aversion to donation are allowed to separate. Families in presumed consent countries infer that non-registered individuals had strong preferences for donation on average, and consent to donation unless the indicator $z$ is small. ${ }^{16}$

Higher family consent rates for non-registered potential donors in conjunction with low registration rates tend to generate equilibria in which presumed consent legislation produces higher donation rates than informed consent legislation. To see this, consider the following numerical example. Let $v$ and $\varepsilon$ be distributed as normal independent variables with mean equal to 0 and variance equal to 1 . Let $c$, the registration cost, be equal to 0.25 . It is easy to show that, for these values of the parameters, $z_{I}=0.4222$, and $V_{I}=[0.5631,1.2815]$ define a pair of equilibrium strategies under informed consent legislation. Similarly, $z_{P}=-0.4222$, and $V_{P}=[-1.2815$, $-0.5631]$ define a pair of equilibrium strategies under presumed consent legislation. ${ }^{17}$

For this example, registration rates are around $18 \%$ under either presumed or informed legislation, even when around $40 \%$ of the individuals have $v>c$ (or $v<-c$ ). In addition, the $18 \%$ registration rate is much lower than the $50 \%$ rate that would arise if the model did not incorporate a registration cost. These equilibria generate donation rates of around $44 \%$ under informed consent legislation and around 56\% under presumed consent legislation, with a difference of around 12 percentage points.

The model described in this section shows that, as a result of a signal-extraction problem, presumed consent defaults may generate higher donation rates than informed consent defaults. However, the model is not unambiguous in this conclusion: it is

\footnotetext{
${ }^{16}$ In reality of course, individuals are always able to separate by communicating preferences for donation directly to their families. However, if the cost of discussing organ donation with family members is high relative to registration costs, then the qualitative predictions of the model still apply.

${ }^{17}$ See Appendix A for the solution of the model under normality.
} 
possible to find examples in which presumed consent laws have zero or negative effect on donation rates. ${ }^{18}$ Moreover, signal-extraction is not the only channel through which legislative defaults may affect organ donation. ${ }^{19}$ Ultimately, whether or not presumed consent laws have an effect on donation rates is an empirical issue. In the next section, we use data on organ donation rates, legislative defaults on cadaveric organ donation, as well as other factors affecting cadaveric organ donation, for a panel of countries to investigate the effect of presumed consent legislation on organ donation rates.

\section{Empirical Analysis}

Despite the worldwide concern about organ shortage for transplantation, few empirical studies have aimed to identify and measure the factors that influence donation rates. The reason may be, in part, that the data required to conduct these studies are not readily available. ${ }^{20}$ This is particularly true concerning information on legislative defaults on organ donation for different countries.

For the empirical analysis in this section, we collected information on legislative defaults for a sample of 36 countries. Figure 3 shows donation rates and type of legislation in 2002 for the 36 countries in our sample. Presumed consent countries seem

\footnotetext{
${ }^{18}$ For example, if most individuals have strong preferences for organ donation and families observe an uninformative indicator of donation preferences, a presumed consent law may create a separating equilibrium in which the few individuals with strong aversion for donation register and do not donate. In the same scenario, an informed consent law may create a pooling equilibrium, in which individuals with strong aversion to donation are not able to separate.

${ }^{19}$ Data from laboratory experiments and observational studies have provided evidence of the existence of a preference to maintain the status-quo that influences individual decision making (see, for example, Samuelson and Zeckhauser, 1988). If a preference to comply with the status-quo exists in the context of organ donation, that by itself will create a direct link between legislative defaults on organ donations and organ donation rates. Moreover, some authors have suggested that presumed consent laws may affect the consent decisions of the families because they change the framing of the request of consent to the families, by creating a strong expectation that consent will be granted (see, for example, Cameron and Forsythe, 2001.)

${ }^{20}$ As Cameron and Forsythe (2001) put it: “... the quantity of hard data on donation remains small, and what is available is often not readily accessible. Neither has all the information been assembled in one place and correlated ..."
} 
to have higher donation rates than informed consent countries. However, the connection between legislative defaults and donation rates is not completely unequivocal. Figure 3 also shows that one country, Spain, has higher donation rates than any other country. This fact is well-documented in the medical literature, where the "Spanish model" of organ procurement has been studied extensively. ${ }^{21}$

For 22 countries in our sample and the period 1993-2002 we obtained information on a number of factors that are thought to affect donation rates, such as per capita GDP, health expenditures per capita, religious beliefs, the legislative system, and the number of deaths caused by motor vehicle accidents and cerebro-vascular diseases. We assembled our dataset using a variety of sources, which are detailed in Appendix B. ${ }^{22}$

In this section, we use regression analysis to study how presumed consent legislation is related to cadaveric organ donation rates, after controlling for other determinants of organ donation.

Table I shows descriptive statistics for the sample of countries used for our regression analysis. Column (1) shows means and standard deviations for the entire sample. Fifty-six percent of the observations in our sample are for presumed consent countries. Columns (2) and (3) show means and standard deviations for presumed consent and informed consent countries, respectively. The last column contains the

\footnotetext{
${ }^{21}$ The Spanish national transplant organization (ONT) is considered the most effective organ procurement organization in the world. Several countries, including Australia and the UK have considered adopting the Spanish organ procurement system, often referred to as the "Spanish model". The "Spanish model" is based on: (i) a system of independent transplant coordination teams, which request consent from families of potential donors so the burden of organ procurement is taken away from transplant surgeons and treating physicians; (ii) a hospital reimbursement policy, which compensates hospitals for organ procurement costs; and (iii) a multi-layered network at the national, regional, and hospital level, which coordinates and manages organ procurement activities. See Matesanz (2001) for details.

${ }^{22}$ To reduce heterogeneity in social norms, we restricted our sample to Western Christian countries (Catholic or Protestant). Appendix B describes our sample selection criteria in detail. Appendix C contains information on legislative defaults on organ donation rates for the 36 countries considered in Figure 3.
} 
differences between columns (2) and (3), along with t-statistics for the null hypothesis of equality of means for presumed and informed consent countries.

It has been pointed out in the medical literature that donation rates are not markedly higher in presumed consent countries (see, e.g., Cameron and Forsythe, 2001). Table I shows that in our sample, informed consent countries have on average 14.19 cadaveric donors per million population per year. Presumed consent countries have on average 17.29 cadaveric donors per million population per year, 3.10 more than informed consent countries. This difference, however, is not significant at conventional test levels. In addition, relative to informed consent countries, presumed consent countries have lower GDP per capita, and lower health expenditures per capita, although again none of these differences is significant at conventional levels. Presumed consent countries are predominantly Catholic, while informed consent laws are the rule in countries with a legislative system based on common law. Finally, the combined mortality rate in motor vehicle accidents (MVA) and cerebro-vascular diseases (CVD) is significantly higher in presumed consent countries.

Table II reports estimated coefficients for the regression of the log of cadaveric donation rates on an indicator of a presumed consent legislative default and other predictors of donation rates. ${ }^{23}$ Column (1) shows that, on average, donation rates are roughly $16 \%$ higher in presumed consent countries. However, this difference is not significant at conventional test levels. Some analysts have argued that the positive difference in donation rates between presumed and informed consent countries may be due to the outlier effect of Spain, which maintains presumed consent legislation. In column (2) we repeat the regression from column (1), this time excluding Spain from our

\footnotetext{
${ }^{23}$ Standard errors are clustered at the country level. All specifications include year fixed-effects.
} 
sample. As expected, the estimated coefficient on the presumed consent legislation indicator decreases relative to column (2) and remains statistically indistinguishable from zero at conventional test levels. Thus, our data support the view in the medical literature that donation rates in presumed consent countries are not much higher on average, relative to informed consent countries.

However, as shown in Table I, the distributions of some potential determinants of donation rates differ between presumed and informed consent countries. In columns (3)(8) of Table II, we include in the regression the other determinants of organ donation considered in Table I. In columns (3) and (4) we include measures of wealth and medical expenditures. ${ }^{24}$ In both cases, the coefficient on the presumed consent variable indicates roughly $26 \%$ higher donation rates in presumed consent countries. This difference is significant at conventional test levels. In columns (5)-(8) we report the results for regression models that include additional variables that measure potentially relevant country characteristics: religious beliefs, whether the country has a common law or a civil law system, and the number of deaths caused by motor vehicle accidents and cerebrovascular diseases. In all cases, including these variables in the regression does not change substantially the value of the coefficient on the presumed consent indicator. This is true even though, as shown in column (6), the variables considered in our regression models explain almost one-third of the variance of the dependent variable $\left(R^{2}=.3216\right)$. In column (8), we show that when other determinants of cadaveric donation rates are accounted for, the coefficient on the presumed consent variable is still large and significant even if we exclude Spain from the sample.

\footnotetext{
${ }^{24}$ The two variables are highly collinear, with health expenditures representing a roughly constant $9 \%-10 \%$ fraction of GDP.
} 
On the whole, the results of Table II show that, when other determinants of donation rates are accounted for, presumed consent countries have roughly $25 \%-30 \%$ higher donation rates than informed consent countries. Moreover, this result is robust to changes in the regression specification. ${ }^{25}$

A potential concern about the analysis in this section is that our results will be biased if unobserved determinants of cadaveric organ donation rates are correlated with the passage of presumed consent laws. In particular, it could be argued that countries where the population have a strong preference for organ donation would be inclined to enact presumed consent laws. In that situation, societal preferences towards organ donation would induce a positive association between presumed consent laws and organ donation rates, and the coefficient on presumed consent in our regressions would be biased upwards. Fixed effects estimators for panel data are often used to control for timeinvariant (additive) confounders. In our sample, legislative defaults on cadaveric organ donation rarely change over time. Therefore, we cannot include country fixed effects in our regression specifications and still identify the coefficient on the presumed consent variable. $^{26}$ However, the absence of time-invariant confounders can be tested in regressions (3) to (8) of Table II, because these regressions include time-varying variables whose coefficients are identified in a specification with country fixed effects. If country effects are correlated with the presence of presumed consent laws, the coefficients on all the variables in our regressions will be biased in the pooled OLS specification, but not in the fixed-effects specification. We use the difference in the

\footnotetext{
${ }^{25}$ In addition to the results reported in Table II, we carried out a specification analysis in which we considered additional variables measuring education (e.g., average years of schooling of adults) and medical infrastructure (e.g., number of hospitals beds per capita). In all cases, the coefficients on the added variables were not statistically significant and their inclusion left the presumed consent coefficient virtually unchanged.

${ }^{26}$ The only country that experiences a change of legislation in our sample is Sweden, which goes from an informed consent system to a presumed consent system in 1996.
} 
coefficients on the time-varying regressors between the pooled OLS and the fixed-effects specifications to test the hypothesis that country effects are uncorrelated with the presence of presumed consent laws. ${ }^{27} \mathrm{P}$-values are reported in Table II for regressions (3) to (8). Our specification test does not detect compelling evidence against the null hypothesis of absence of confounding country effects.

Although our specification test produces encouraging results about the validity of our estimates, it should be clear that the statistical power of our test will be low against deviations from the null hypothesis that affect mainly the estimated coefficient on the presumed consent law, but not the coefficients on the time-varying regressors. An alternative approach to the potential endogeneity of presumed consent laws is to include in our regressions a proxy for societal preferences towards organ donation. We follow this approach in Table III, where we use annual blood donations (per capita) as an indicator of societal preferences towards organ donation. ${ }^{28}$ Columns (1) and (2) of Table III reproduce the specifications in columns (6) and (7) of Table II, but this time including the logarithm of annual blood donations per 1,000 population as an additional regressor. As expected, donations of blood are positively associated with donations of organs. However, the estimated coefficients on the presumed consent variable increase relative to Table II. This is at odds with the notion that nations with stronger preferences towards organ donation will be inclined to enact presumed consent laws. In fact, columns (3) and (4) of Table III show that social preferences towards organ donation proxied as the log of blood donations per 1,000 population have, if anything, a negative correlation with the presence of presumed consent laws (although the coefficients on the log of blood

\footnotetext{
${ }^{27}$ This test is implemented as a generalized Hausman specification test (see White, 1996).

${ }^{28}$ Arguably, donations of blood are motivated by the same philanthropic considerations as organ donations. Other indicators of the propensity to donate, like the fraction of the population who do unpaid work for voluntary organizations, produced similar results.
} 
donations per 1,000 population in columns (3) and (4) are not significant at conventional test levels). Overall, the robustness analysis reported in Table III fails to detect any evidence that the empirical results in Table II are confounded by cross-country differences in social norms towards organ donation.

On the whole, our empirical results suggest that presumed consent laws may greatly increase the supply of cadaveric organs for transplantation. However, it would be erroneous to interpret our results as evidence that presumed consent is the sometimesportrayed silver-bullet for organ shortage. First, it is unlikely that a $25 \%$ to $30 \%$ increase in cadaveric donation would eliminate completely the organ shortage problem in some countries, like the U.S., although it would help considerably to alleviate it. To see this assume that percentage increases in cadaveric donations translate roughly to percentage increases in cadaveric transplantation. Table IV in column (1) shows the range for the number of additional transplantations that a $25 \%$ to $30 \%$ increase in cadaveric transplantations would have represented in the U.S. for the period of 1995-2002. For the same period, columns (2) and (3) show the yearly change in the number of patients on waiting lists and the yearly number of deaths on the waiting list, respectively. Columns (4) to (6) show the same variables for the U.K. and the period 1994-2001. The figures in Table IV suggest that a $25 \%$ to $30 \%$ increase in cadaveric transplantation could potentially close the gap between the demand and the supply of organs in the U.K., but not in the U.S. Moreover, it seems likely that an increase in the supply of cadaveric organs would be followed by a reduction in the supply of organs from living donors. Substitution of organs from living donors would attenuate the effect of an increase in 
cadaveric organs on the size of the waiting lists. ${ }^{29}$ Finally, many questions remain unanswered about how to implement a legislative change of this type. Although recent studies have reported successful transitions to a presumed consent default (see, for example, Michielsen, 1996), it seems likely that in some countries the imposition of a presumed consent law, without building first sufficient social support, could generate an adverse response towards organ procurement efforts.

\section{Conclusions}

Previous studies have pointed out that, on average, presumed consent countries do not produce significantly higher organ donation rates. Moreover, several authors have hypothesized that this lack of correlation is produced by the fact that presumed consent laws are rarely enforced and that, in practice, family consent is always required before organs are extracted.

In this article, we argue that legislative defaults on organ donation may affect the consent decisions of the families, even if they are not enforced. First, we use a simple model to illustrate how presumed consent laws may affect organ donation rates. In addition, using a panel of countries, we show that, once other determinants of organ donation are accounted for, cadaveric donation rates are $25 \%$ to $30 \%$ higher in presumed consent countries. The magnitude of this estimate does not vary much across the different specifications of our empirical model. Furthermore, using the panel structure of our data we are able to reject the presence of additive fixed effects.

\footnotetext{
${ }^{29}$ This substitution effect is difficult to quantify because, to our knowledge, there do not exist estimates of the elasticity of substitution between living donor organs and cadaveric organs. In addition, it is possible that a higher availability of organs would be followed by an increase in the number of referrals to the waiting lists.
} 
Health professionals and organ donation activists in the U.S., Great Britain, and several other countries have proposed changing legislative defaults on organ donation to presumed consent. The results of this article suggest that presumed consent laws may alleviate organ shortages. Further research is needed, however, to understand better how societies perceive and respond to legislative changes of this nature. 


\section{References}

AMA. 1994. Council of Ethical and Judicial Affairs, American Medical Association. "Strategies for Cadaveric Organ Procurement: Mandated Choice and Presumed Consent." Journal of the American Medical Association, 272(10), 809-812.

An, Mark Y. 1998. "Logconcavity versus Logconvexity: A Complete Characterization." Journal of Economic Theory, 80, 350-369.

ANZOD. 2003. The Australia and New Zealand Organ Donation Registry. 2002 Annual Report. http://www.anzdata.org.au/ANZOD/ANZODReport/anzodreport.htm

Barber, Kerri M., Julie C. Hussey, Zoe C. Bond, Dave Collett and Chris J. Rudge. 2003. "Potential Donor Audit." Poster presented at 'State of the Art Conference'. Intensive Care Society. London, (November).

Becker, Gary S. and Julio J. Elias. 2003. "Financial Incentives for Live Organ Donation." Working paper. University of Chicago.

Byrne Margaret, Peter Thompson, 2001. "A Positive Analysis of Financial Incentives for Cadaveric Organ Donation.” Journal of Health Economics 20(1), 69-83.

Cameron, Stuart and John Forsythe. 2001. "How Can We Improve Organ Donation Rates? Research into the Identification of Factors which May Influence the Variation." Nefrología 21, 68-77.

Choi, James, J., David Laibson, Brigitte C. Madrian, and Andrew Metrick. 2003. "Optimal Defaults." American Economic Review (Papers and Proceedings), 93(2), $180-185$.

CIA. The World Factbook. 2003. http://www.cia.gov/cia/publications/factbook/.

EFG. Etablissement Francais des Greffes. 2004. "Rapport d'activité et Bilan des activités de prélèvement et de greffe en France Année 2002." http://www.efg.sante.fr/fr/rapport/.

Feltovich, Nick, Rick Harbaugh, and Ted To. 2002. "Too cool for school? Signaling and countersignaling." RAND Journal of Economics, vol. 33(4), (Winter), 630-649.

FIODS. Fédération Internationale des Organisations des Donneurs de Sang. 2004. http://www.fiods.org.

Gallup Inc. 1993. "The American Public's Attitudes toward Organ Donation and Transplantation." Conducted for The Partnership for Organ Donation, Boston.

Gimbel, Ronald W., Martin A. Strosberg, Susan E. Lehrman, Eugenijus Gefenas and Frank Taft. 2003. "Presumed Consent and Other Predictors of Cadaveric Organ Donation in Europe." Transplant. 13-17. 
Inglehart, Ronald, et al. World Values Surveys and European Values Surveys, 19992001. Inter-university Consortium for Political and Social Research, 2004.

Johnson, Eric J. and Daniel G. Goldstein. 2003. "Do defaults save lives?" Science 302, 1338-1339.

Krishna, Vijay. 2002. Auction Theory. Academic Press, London.

Madrian, Brigitte.C. and Dennis F. Shea. 2001. "The Power of Suggestion: Inertia in 401(k) Participation and Savings Behavior." Quarterly Journal of Economics, 116(4), 1149-1187.

Matesanz, Rafael. 2001. "A Decade of Continuous Improvement in Cadaveric Organ Donation: the Spanish Model." Nefrología 21, 59-67.

Michielsen, Paul. 1996. "Presumed Consent to Organ Donation: Ten Years' Experience in Belgium." Journal of the Royal Society of Medicine 89, 663-666.

Nathan, Howard M., Suzanne L. Conrad, Philip J. Held, Keith P. McCullough, Richard E. Pietroski, Laura A. Siminoff and Akinlolu O. Ojo. 2003. "Organ Donation in the United States." American Journal of Transplantation 3(4), 29-40.

ONT. Organización Nacional de Transplantes. 2003. Estadísticas. http://www.msc.es/profesional/trasplantes/estadisticas/estadisticas.htm.

OPTN. The Organ Procurement and Transplantation Network. 2003. Data. http://www.optn.org/data/.

Oz Mehmet C., Aftab R. Kherani, Amanda Rowe, Leo Roels, Chauncey Crandall, Luis Tomatis and James B. Young. 2003. "How to Improve Organ Donation: Results of the ISHLT/FACT Poll." The Journal of Heart and Lung Transplantation 22(2) (April), 389-410.

Roth, Alvin E., Tayfun Sonmez and M. Utku Unver. 2004. "Kidney Exchange." Quarterly Journal of Economics, 119(2), 457-488.

Samuelson, William and Richard Zeckhauser. 1988. "Status-Quo Bias in Decision Making." Journal of Risk \& Uncertainty, 1(1) (March), 7-59.

Siminoff, Laura, Nahida Gordon, Joan Hewlett and Robert Arnold. 2001. "Factors Influencing Families' Consent for Donation of Solid Organs for Transplantation." Journal of the American Medical Association 286(1), 71-77.

Sunstein, Cass R, and Richard H. Thaler. 2003. "Libertarian Paternalism Is Not an Oxymoron." University of Chicago Law Review, 70(4) (Fall), 1159-1202.

Thaler, Richard H., and Cass R. Sunstein. 2003. "Libertarian Paternalism." American Economic Review (Papers and Proceedings), 93(2), 175-179. 
TMP. International Registry Organ Donation Transplantation. 2003. Transplant Procurement Management. http://www.tpm.org/registry/reg mondo.htm.

UK Transplant. Statistics. 2003. http://www.uktransplant.org.uk/.

UNOS. United Network for Organ Sharing. 2002. "Annual Report of the U.S. Organ Procurement and Transplantation Network and the Scientific Registry of Transplant Recipients: Transplant Data 1992-2001". http://www.optn.org/data/annualReport.asp.

Votruba, Mark E. 2001. "Efficiency-Equity Tradeoffs in the Allocation of Cadaveric Kidneys." Working Paper. Princeton University.

White, Halbert. 1996. Estimation, Inference and Specification Analysis. Cambridge University Press: New York.

World Bank. World Development Indicators, 2003a.

World Bank. Education Statistics. http://devdata.worldbank.org/edstats/cd5.asp, 2003b.

World Health Organization. 2003. WHO Mortality Database.

http://www3.who.int/whosis/. 


\section{Appendix A: Technical Details}

\section{Affiliated random variables}

Lemma 1: Suppose that the density of $\varepsilon$ is log-concave and that $\varepsilon$ and $v$ are independent. Let $z=v+\varepsilon$. Then, $z$ and $v$ are affiliated, that is, for all $\bar{z} \geq \underline{z}$ and $\bar{v} \geq \underline{v}$

$$
f_{z, v}(\bar{z}, \underline{v}) f_{z, v}(\underline{z}, \bar{v}) \leq f_{z, v}(\underline{z}, \underline{v}) f_{z, v}(\bar{z}, \bar{v})
$$

where $f_{z, v}$ is the density of $(z, v)$.

Proof: Because $\varepsilon$ and $v$ are independent, we obtain

$$
f_{z, v}(z, v)=f_{\varepsilon}(z-v) f_{v}(v)
$$

Therefore, $z$ and $v$ are affiliated if and only if

$$
f_{\varepsilon}(\bar{z}-\underline{v}) f_{\varepsilon}(\underline{z}-\bar{v}) \leq f_{\varepsilon}(\underline{z}-\underline{v}) f_{\varepsilon}(\bar{z}-\bar{v})
$$

In other words, the density $f_{\varepsilon}$ is of Pólya frequency of order 2, which is equivalent to $\log$-concavity of $f_{\varepsilon}$ (see An, 1998).

Lemma 2: Suppose that $z=v+\varepsilon$, where $\varepsilon$ is independent of $v$ and has a log-concave density. Let $z_{I}, z_{P}$, and $c$ be real numbers with $c>0$. Then,

$$
V_{I}=\left\{v: v \operatorname{Pr}\left(z \leq z_{I} \mid v\right)>c\right\} \text { and } V_{P}=\left\{v: v \operatorname{Pr}\left(z \geq z_{P} \mid v\right)<-c\right\}
$$

are either intervals or empty sets.

Proof: It can be shown that log-concave densities have convex supports (An, 1998). Let $g(v)=v F_{\varepsilon}\left(z_{I}-v\right)$. Notice that $g(0)=0$. In addition $\lim _{v \rightarrow \infty} g(v)=0$, because logconcave densities have at most exponential tails (An, 1998). The right-hand-side derivative of $g(v)$ is $F_{\varepsilon}\left(z_{I}-v\right)-v f_{\varepsilon}\left(z_{I}-v\right)$. Notice that $F_{\varepsilon}\left(z_{I}-v\right)-v f_{\varepsilon}\left(z_{I}-v\right)$ converges to one when $v \rightarrow-\infty$, and it converges to zero when $v \rightarrow \infty$. If the support of $\varepsilon$ is bounded from below, $F_{\varepsilon}\left(z_{I}-v\right)-v f_{\varepsilon}\left(z_{I}-v\right)$ is equal to zero if $z_{I}-v$ is to the left of the support of $\varepsilon$. If the support of $\varepsilon$ is bounded from above, $F_{\varepsilon}\left(z_{I}-v\right)-v f_{\varepsilon}\left(z_{I}-v\right)$ is equal to one if $z_{I}-v$ is to the right of the support of $\varepsilon$. If $z_{I}-v$ belongs to the support of $\varepsilon$, then $F_{\varepsilon}\left(z_{I}-v\right)-v f_{\varepsilon}\left(z_{I}-v\right)$ has the same sign as $F_{\varepsilon}\left(z_{I}-v\right) / f_{\varepsilon}\left(z_{I}-v\right)-v$. By the properties of $\log$-concave densities, the ratio $F_{\varepsilon}\left(z_{I}-v\right) / f_{\varepsilon}\left(z_{I}-v\right)$ is a nonincreasing function of $v$. Thus, $F_{\varepsilon}\left(z_{I}-v\right) / f_{\varepsilon}\left(z_{I}-v\right)-v$ is decreasing, so the function 
$g(v)$ is quasi-concave. Now, the result for $V_{I}$ follows from the properties of quasiconcave functions. The proof for $V_{P}$ is analogous.

\section{Solution of the model under normality}

Assume that $\mathrm{v} \sim N\left(\mu_{\mathrm{v}}, \sigma_{v}{ }^{2}\right)$ and $\varepsilon \sim N\left(0, \sigma_{\varepsilon}{ }^{2}\right)$. Consider first the informed consent scenario:

$$
\operatorname{Pr}\left(z \leq z_{I} \mid \mathrm{v}\right)=\operatorname{Pr}\left(\frac{\varepsilon}{\sigma_{\varepsilon}} \leq \frac{z_{I}-v}{\sigma_{\varepsilon}} \mid \mathrm{v}\right)=\Phi\left(\frac{z_{I}-v}{\sigma_{\varepsilon}}\right)
$$

where $\Phi$ represents the cumulative distribution function of the standard normal distribution. For this case, the set of individuals registering under informed consent legislation,

$$
V_{I}=\left\{v: v \Phi\left(\frac{z_{I}-v}{\sigma_{\varepsilon}}\right)>c\right\}
$$

is an interval $\left[\underline{c}_{I}\left(z_{I}\right), \bar{c}_{I}\left(z_{I}\right)\right]$ or the empty set. Given that

$$
f_{v \mid v+\varepsilon=z}=\frac{f_{v+\varepsilon \mid v=v}(z)}{f_{v+\varepsilon}(z)} f_{v}(v)=\frac{f_{\varepsilon}(z-v) f_{v}(v)}{f_{v+\varepsilon}(z)}
$$

we obtain:

$$
\begin{aligned}
& E\left[v \mid v \operatorname{Pr}\left(z \leq z_{I} \mid v\right)<c, v+\varepsilon=z_{I}\right] \\
& \qquad \int_{-\infty}^{c_{I}\left(z_{I}\right)} v \frac{1}{\sigma_{\varepsilon}} \frac{1}{\sigma_{v}} \phi\left(\frac{z_{I}-v}{\sigma_{\varepsilon}}\right) \phi\left(\frac{v-\mu_{v}}{\sigma_{v}}\right) d v+\int_{\bar{c}_{I}\left(z_{I}\right)}^{+\infty} v \frac{1}{\sigma_{\varepsilon}} \frac{1}{\sigma_{v}} \phi\left(\frac{z_{I}-v}{\sigma_{\varepsilon}}\right) \phi\left(\frac{v-\mu_{v}}{\sigma_{v}}\right) d v,
\end{aligned}
$$

where $\phi$ represents the probability density function of the standard normal distribution. Therefore, the solution for $z_{I}$ is given by:

$$
\int_{-\infty}^{\underline{c}_{I}\left(z_{I}\right)} v \phi\left(\frac{z_{I}-v}{\sigma_{\varepsilon}}\right) \phi\left(\frac{v-\mu_{v}}{\sigma_{v}}\right) d v+\int_{\bar{c}_{I}\left(z_{I}\right)}^{+\infty} v \phi\left(\frac{z_{I}-v}{\sigma_{\varepsilon}}\right) \phi\left(\frac{v-\mu_{v}}{\sigma_{v}}\right) d v=0
$$

Notice that

$$
\phi\left(\frac{z_{I}-v}{\sigma_{\varepsilon}}\right) \phi\left(\frac{v-\mu_{v}}{\sigma_{v}}\right) \propto \exp \left\{-\frac{1}{2}\left[\left(\frac{z_{I}-v}{\sigma_{\varepsilon}}\right)^{2}+\left(\frac{v-\mu_{v}}{\sigma_{v}}\right)^{2}\right]\right\} .
$$


In addition,

$$
\begin{aligned}
\left(\frac{z_{I}-v}{\sigma_{\varepsilon}}\right)^{2}+\left(\frac{v-\mu_{v}}{\sigma_{v}}\right)^{2}=\frac{z_{I}{ }^{2}+v^{2}-2 z_{I} v}{\sigma_{\varepsilon}{ }^{2}}+\frac{\mu_{v}{ }^{2}+v^{2}-2 \mu_{v} v}{\sigma_{v}{ }^{2}} & \frac{1}{\sigma_{\varepsilon}{ }^{2} \sigma_{v}{ }^{2}}\left\{\left(\sigma_{v}{ }^{2}+\sigma_{\varepsilon}{ }^{2}\right) v^{2}-2\left(\sigma_{v}{ }^{2} z_{I}+\sigma_{\varepsilon}{ }^{2} \mu_{v}\right) v+\left(\sigma_{v}{ }^{2} z_{I}{ }^{2}+\sigma_{\varepsilon}{ }^{2} \mu_{v}{ }^{2}\right)\right\} \\
= & \frac{\sigma_{\varepsilon}{ }^{2}+\sigma_{v}{ }^{2}}{\sigma_{\varepsilon}{ }^{2} \sigma_{v}{ }^{2}}\left\{v^{2}-2\left(\frac{\sigma_{v}{ }^{2} z_{I}+\sigma_{\varepsilon}{ }^{2} \mu_{v}}{\sigma_{\varepsilon}{ }^{2}+\sigma_{v}{ }^{2}}\right) v+\frac{\sigma_{v}{ }^{2} z_{I}{ }^{2}+\sigma_{\varepsilon}{ }^{2} \mu_{v}{ }^{2}}{\sigma_{\varepsilon}{ }^{2}+\sigma_{v}{ }^{2}}\right\} \\
= & \frac{\sigma_{\varepsilon}{ }^{2}+\sigma_{v}{ }^{2}}{\sigma_{\varepsilon}{ }^{2} \sigma_{v}{ }^{2}}\left\{v^{2}-2\left(\frac{\sigma_{v}{ }^{2} z_{I}+\sigma_{\varepsilon}{ }^{2} \mu_{v}}{\sigma_{\varepsilon}{ }^{2}+\sigma_{v}{ }^{2}}\right) v+\left(\frac{\sigma_{v}{ }^{2} z_{I}+\sigma_{\varepsilon}{ }^{2} \mu_{v}}{\sigma_{\varepsilon}{ }^{2}+\sigma_{v}{ }^{2}}\right)^{2}\right\}+C
\end{aligned}
$$

where $C$ is some constant. As a result:

$$
\phi\left(\frac{z_{I}-v}{\sigma_{\varepsilon}}\right) \phi\left(\frac{v-\mu_{v}}{\sigma_{v}}\right) \propto \phi\left(\frac{v-\mu_{I}}{\sigma}\right)
$$

where

$$
\mu_{I}=\frac{\sigma_{v}{ }^{2} z_{I}+\sigma_{\varepsilon}{ }^{2} \mu_{v}}{\sigma_{\varepsilon}{ }^{2}+\sigma_{v}{ }^{2}} \quad \text { and } \quad \sigma^{2}=\frac{\sigma_{\varepsilon}{ }^{2} \sigma_{v}{ }^{2}}{\sigma_{\varepsilon}{ }^{2}+\sigma_{v}{ }^{2}}
$$

It is easy to show that

$$
\int_{-\infty}^{\underline{v}} v \frac{1}{\sigma} \phi\left(\frac{v-\mu}{\sigma}\right) d v=\mu \Phi\left(\frac{\underline{v}-\mu}{\sigma}\right)+\sigma \int_{-\infty}^{\frac{\underline{v}-\mu}{\sigma}} y \phi(y) d y=\mu \Phi\left(\frac{\underline{v}-\mu}{\sigma}\right)-\sigma \phi\left(\frac{\underline{v}-\mu}{\sigma}\right)
$$

and

$$
\int_{\bar{v}}^{+\infty} v \phi\left(\frac{v-\mu}{\sigma}\right) d v=\mu\left(1-\Phi\left(\frac{\bar{v}-\mu}{\sigma}\right)\right)+\sigma \phi\left(\frac{\bar{v}-\mu}{\sigma}\right)
$$

Hence, the solution for the cutoff point, $z_{I}$, is given by:

$$
\mu_{I} \Phi\left(\frac{\underline{c}_{I}\left(z_{I}\right)-\mu_{I}}{\sigma}\right)-\sigma \phi\left(\frac{\underline{c}_{I}\left(z_{I}\right)-\mu_{I}}{\sigma}\right)+\mu_{I}\left(1-\Phi\left(\frac{\bar{c}_{I}\left(z_{I}\right)-\mu_{I}}{\sigma}\right)\right)+\sigma \phi\left(\frac{\bar{c}_{I}\left(z_{I}\right)-\mu_{I}}{\sigma}\right)=0
$$

For the presumed consent case, the result is analogous: 


$$
\mu_{P} \Phi\left(\frac{\underline{c}_{P}\left(z_{P}\right)-\mu_{P}}{\sigma}\right)-\sigma \phi\left(\frac{\underline{c}_{P}\left(z_{P}\right)-\mu_{P}}{\sigma}\right)+\mu_{P}\left(1-\Phi\left(\frac{\bar{c}_{P}\left(z_{P}\right)-\mu_{P}}{\sigma}\right)\right)+\sigma \phi\left(\frac{\bar{c}_{P}\left(z_{P}\right)-\mu_{P}}{\sigma}\right)=0
$$

with

$$
\mu_{P}=\frac{\sigma_{v}^{2} z_{P}+\sigma_{\varepsilon}^{2} \mu_{v}}{\sigma_{\varepsilon}^{2}+\sigma_{v}^{2}}
$$




\section{Appendix B: Data Sources and Sample Selection}

International data on cadaveric organ donation rates come from the Spanish National Organ Transplantation Organization (ONT, 2003) and the Transplant Procurement Management Organization (TPM, 2003). Disaggregated data for the U.K. and Ireland were provided by Kerri Burbidge from UK Transplant. Data on organ donation for the U.S. come from OPTN (2003). Data on organ donation rates for New Zealand come from ANZOD (2003). For the U.S., data on cadaveric transplantation, size of waiting lists, and number of deaths on waiting lists come from OPTN (2003). For the U.K., data on cadaveric transplantation and size of waiting lists come from UK Transplant (2003), and data on deaths on waiting lists was provided to us by Kerri Burbidge from UK Transplant.

Data on legislative defaults on cadaveric organ donations were compiled from a variety of sources by consulting the legal literature. In some instances, when legislative data for a particular country could not be found in the literature or the information was ambiguous, we contacted the country agency in charge of organ donation management to request this information. Detailed information about legislative defaults on cadaveric organ donation is presented in Appendix C.

We obtained data on GDP, population, health expenditures, and number of hospital beds from the World Bank Development Indicators (World Bank, 2003a). Schooling data appear in the World Bank Education Statistics (World Bank, 2003b). The number of deaths caused by traffic accidents and cerebro-vascular failures were compiled from the World Health Organization Mortality Database (World Health Organization, 2003). We obtained data on religious beliefs and legal systems from CIA (2003). Data on blood donation refer to the year 2001. For Europe and North America these data come 
from FIODS (2004). Data on blood donation for New Zealand was provided by Paul Hayes from the New Zealand Blood Service. Data on the fraction of the population doing unpaid work for voluntary organizations come from the World Values Survey (Inglehart et al, 2004).

For the 36 countries listed in Appendix C and in Figure 3 and for the year 2002, we obtained data on cadaveric organ donation rates and legislative defaults on cadaveric organ donation. Fourteen of the 36 countries were discarded for the regression analysis in section IV. Countries were discarded for several reasons. First, to reduce heterogeneity in social norms we restricted our sample to Western Christian countries (Catholic and Protestant). This eliminated from our sample Bulgaria, Greece, Israel, Japan, Romania, and Turkey. Some countries, Bulgaria, Croatia, Cyprus, Estonia, Japan, Latvia, Lithuania, and Romania, were discarded also because of data availability problems. An additional reason to discard Japan was that heart-beating cadaveric donation was outlawed in Japan until recently. We also discarded small countries with less than one million population, like Cyprus and Luxembourg. We discarded Switzerland, because, although this country has an informed consent default at the federal level, legislation on organ donation defaults varies by region. Finally, some countries produce extremely modest levels of organ transplant activity, which, in some cases, may be caused by lack of transplantation facilities. If capacity constraints limit the transplantation activity in a country at a very low level, legislative defaults are unlikely to influence donation rates, because organs will not be used for transplantation. Including in our sample countries with capacity constraints on organ transplantation would bias down our estimate of the effect of presumed consent laws in countries where capacity constraints are not binding. For this reason, we discarded those countries which never reached a rate of 20 kidney transplants 
per million population per year. These countries are: Croatia, Greece, Slovak Republic, Romania, and Turkey. In principle, this could create a bias in our estimates if the cause of low transplant rates in those countries is a low cadaveric organ donation rate. However, we chose the rate of kidney transplants to select our sample because kidneys can be procured from living donors if transplant facilities are available. In practice, capacity, and not cadaveric donation, is likely to be the binding constraint for countries with fewer than 20 kidney transplants per million population per year. In the U.S., for example, transplants of kidneys procured from living donors routinely surpass the 20 pmp rate. In Cyprus, where cadaveric donations are almost non-existent, the rate of kidney transplants from living donors goes consistently beyond the $55 \mathrm{pmp}$ mark.

The 22 countries used in our regression analysis are: Australia, Austria, Belgium, Canada, Czech Republic, Denmark, Finland, France, Germany, Hungary, Ireland, Italy, The Netherlands, New Zealand, Norway, Poland, Portugal, Slovenia, Spain, Sweden, United Kingdom, and the United States. 


\section{Appendix C: Legislative Defaults on Cadaveric Organ Donation}

Australia: Informed consent country by Law of 1982 . Has a donor registry since November 2000.

Austria: Presumed consent country by Law of 1 June 1982, Section 62A. Has a nondonor registry since 1995 . The principle of presumed consent is enforced.

Belgium: Presumed consent country by Law of 13 June 1986. Has a combined registry since 1987 . Families should be informed and could potentially object to organ donation.

Bulgaria: Presumed consent country by Law of 1996. In practice, consent from the next of kin is required.

Canada: Informed consent country by Uniform Human Tissue Donation Act of 1980. (The exact date depends on each state: Alberta: Human Tissue Act 1967. British Columbia: Human Tissue Gift Act 1974. Manitoba: Human Tissue Gift Act 1987. New Brunswick: Human Tissue Gift Act 1973 and Human Tissue Gift Act 1986.

Newfoundland: Act No 78 of 1966. Nova Scotia: Human Tissue Gift Act 1964. Ontario: Human Tissue Gift Act 1982. Prince Edward Island: Human Tissue Donation Act 1992 Quebec: Civil Law of 1993 Articles 42,43, 44.)

Croatia: Presumed consent country by Law of 2000; was already a presumed consent country since 1989 . No donor registry in place. Family consent is always requested.

Cyprus: Presumed consent country by Law No 97 of 1987.

Czech Republic: Presumed consent country by Law of 1984. A new law was passed on September 2002 that established a stronger version of presumed consent. No registry in place for non-donors.

Denmark: Informed consent country by Law No 402v of 13 June 1990. Previously, Denmark was a presumed consent country by Law No 246 of 9 June 1967. Denmark has a combined registry since 1990.

Estonia: Presumed consent country.

Finland: Presumed consent country by Law No 355 of 26 April 1985 and Ordinance No 724 of 23 August 1985.

France: Presumed consent country by Caillavet Law (No 76-1181) of 22 December 1976 and the Bioethics Law No 94-654 of 29 July 1994. France has a non-donor registry since 1990, as well as a donor card system. In practice, families can override the intent of deceased relatives. 
Germany: Informed Consent country by Act on the Donation, Removal and Transplantation of Organs of 5 November 1997. Previously, Germany was also informed consent. There is no registry in place.

Greece: Presumed consent country by Law 2737 of August 27 1999. It was already a presumed consent country by Law of 1978 (No 821) modified in 1983 (Law No 1383 of the 2 August 1983).

Hungary: Presumed consent country by Ordinance No 18 of 4 November 1972. Has a non-donor registry since 1999.

Ireland: Informed consent country. The Republic of Ireland does not have a law regulating organ donation, but follows U.K. guidelines.

Israel: Presumed consent country by the Law of Anatomy and Pathology of 1953.

Italy: Presumed consent country by Penal Code, Articles 581-5 and Law No 458 of 26 June 1967, Law No 644 of 2 December 1975. A new law of presumed consent was approved on April 1st 1999. Has a combined registry since 2000. In practice, families are consulted before organs are extracted.

Japan: Informed consent country by Law No 104 of 16 July 1997. Before 1997, heart beating donors were not allowed. According to section 6(1) of the Law of 16 July 1997, families can veto decisions of relatives to donate.

Latvia: Presumed consent country.

Lithuania: Informed consent country.

Luxemburg: Presumed consent country by Law of 25 November 1982.

The Netherlands: Informed consent country by Law of 24 May 1996. Before 1996, the country was already informed consent. There is a combined registry in place since 1998 . Families decide on donation for non-registered relatives, but have a small influence in the decision for registered relatives.

New Zealand: Informed consent country by the Human Tissue Act of 1964 .

Norway: Presumed consent country by Law No 6 of 9 February 1973. There is no registry in place. Families are consulted before organ extraction and can potentially refuse. If no relatives are found, organs can be extracted. Patients organizations have introduced donor cards, but they do not have legal status.

Poland: Presumed consent country by Article No 91-408 of August 301990 law and article 4 of October 1995 law. There is a non-donor registry in place since 1996.

Portugal: Presumed consent country by Law No 12 of 22 April 1993. There is a nondonor registry in place since 1994. 
Romania: Informed consent country by Law of 1998. Previously, Romania was already an informed consent. There is a combined registry in place since 1996.

Slovak Republic: Presumed consent country by Law of 24 August 1994, section 47.

Slovenia: Presumed consent country by Law of 2000. Previously, Slovenia was already presumed consent, by the Law of Transplantation of Human's Body Parts of 1996.

Spain: Presumed consent country by Law No 30 of 30 October 1979. In practice, organs are extracted only with the consent of families.

Sweden: Presumed consent country by Law of 1996. Between 1987 and 1996, Sweden was an Informed Consent country. Families can potentially veto donation if the wishes of the deceased relative are not known. There is a combined registry in place, although it is used mainly as a non-donor registry.

Switzerland: Informed consent country by Federal Order of 22 March 1996. However, the country is divided in cantons that have their own legislation. The following cantons have presumed consent legislation: Appenzell (laws of 1974 and 1992), Argovie (1987), Bale-Campagne (1988), Bale-Ville (1981), Berne (1984), Geneva (1996), Grisons (1984), Lucerne (1981), Neuchatel (1995), Nidwald (1981), St-Gall (1979), Turgovia (1985), Valais (1996), Vaud (1985), and Zurich (1991).

Turkey: Presumed consent country by Law No 2238 of June 3, 1979. In practice, written authorization from families has to be obtained before organ extraction.

United Kingdom: Informed consent country by The Human Tissue Act 1961 and the The Human Organ Transplants Act 1989. Has a donor registry since 1994.

United States: Informed consent country by National Organ Transplants Act of 1984. There are donor registries in 14 states; donor registries are being considered in other states.

A longer version of this appendix, including sources, is available from the authors on request. 
Figure 1. Number of patients waiting for organs, USA and UK

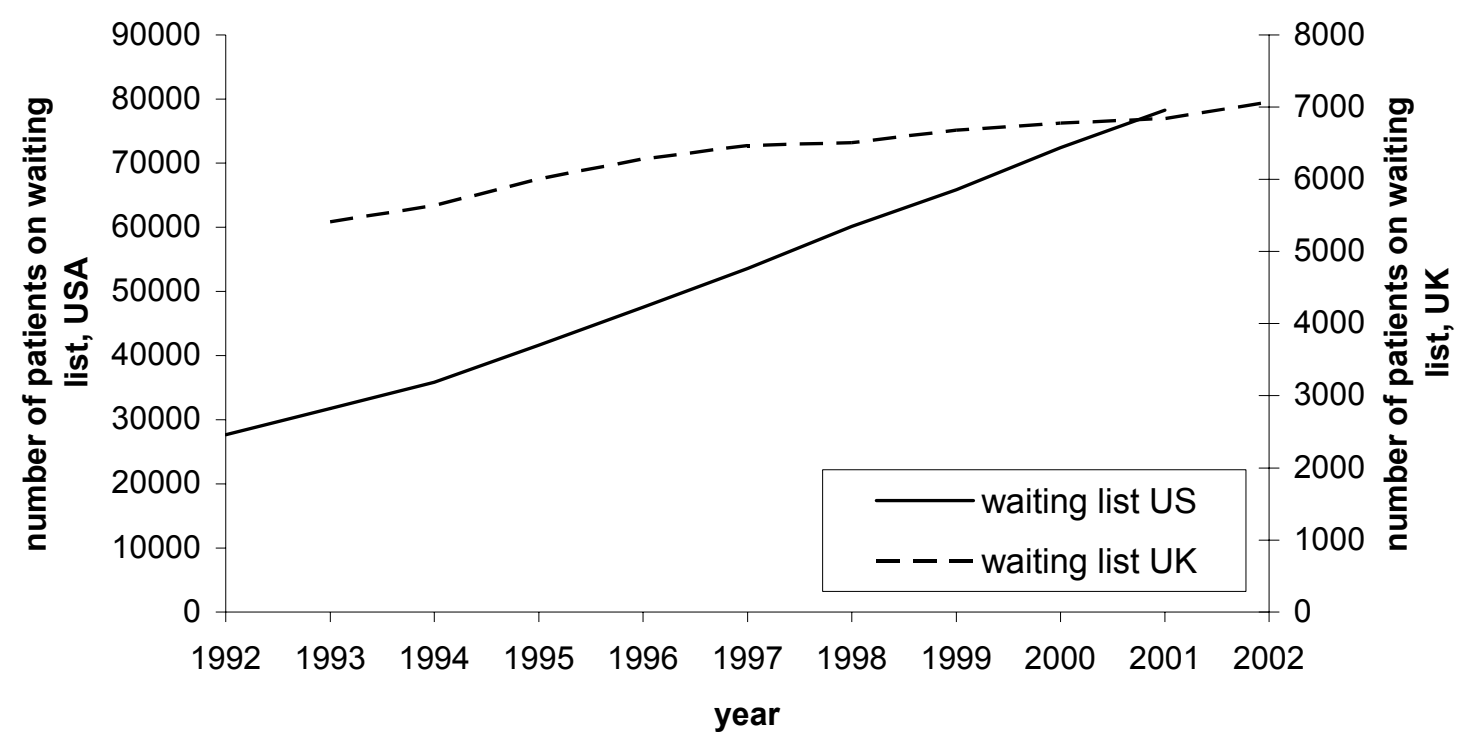


Figure 2. Registration and consent decisions in the model
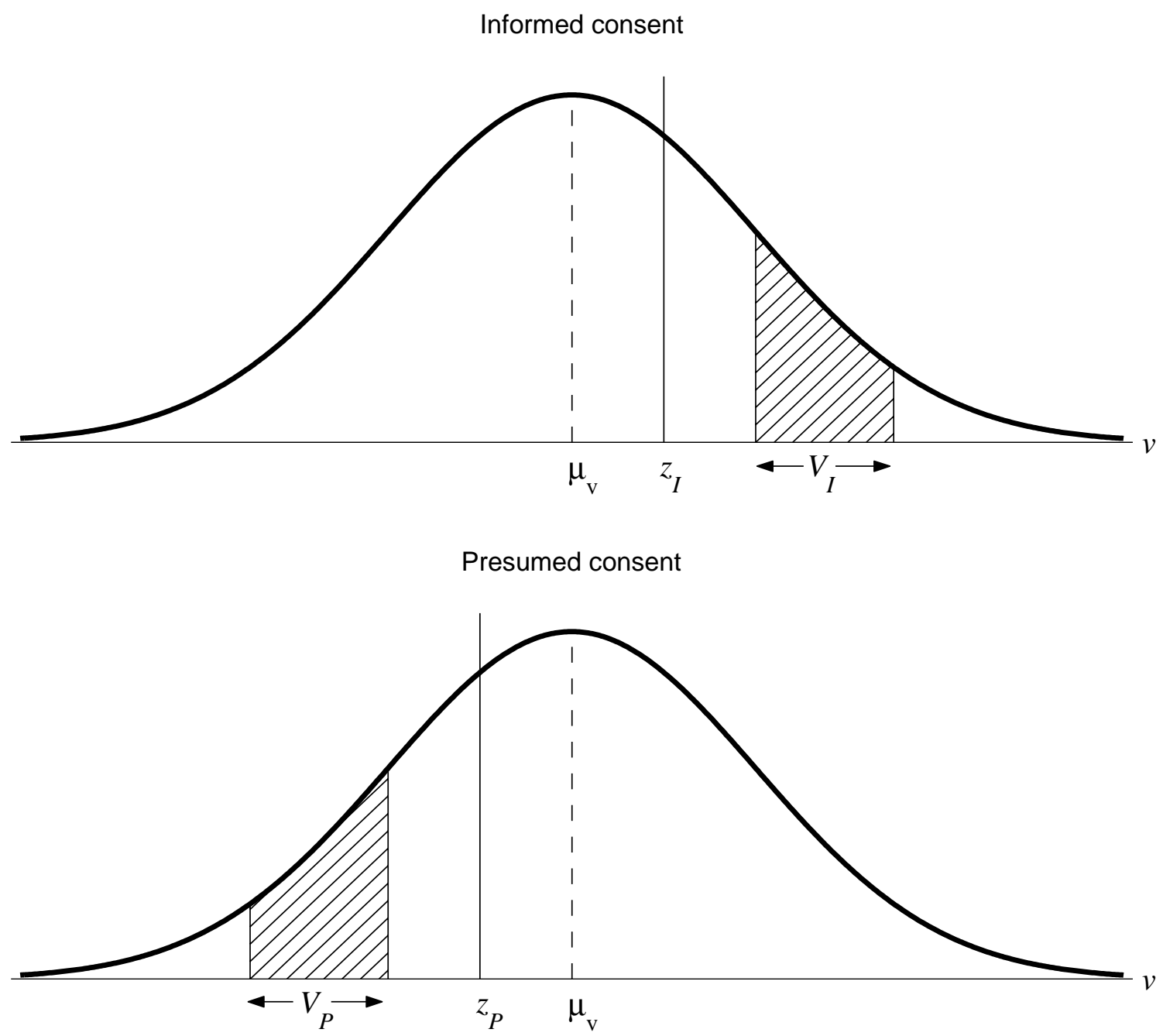
Figure 3. Cadaveric Donation Rates in 2002

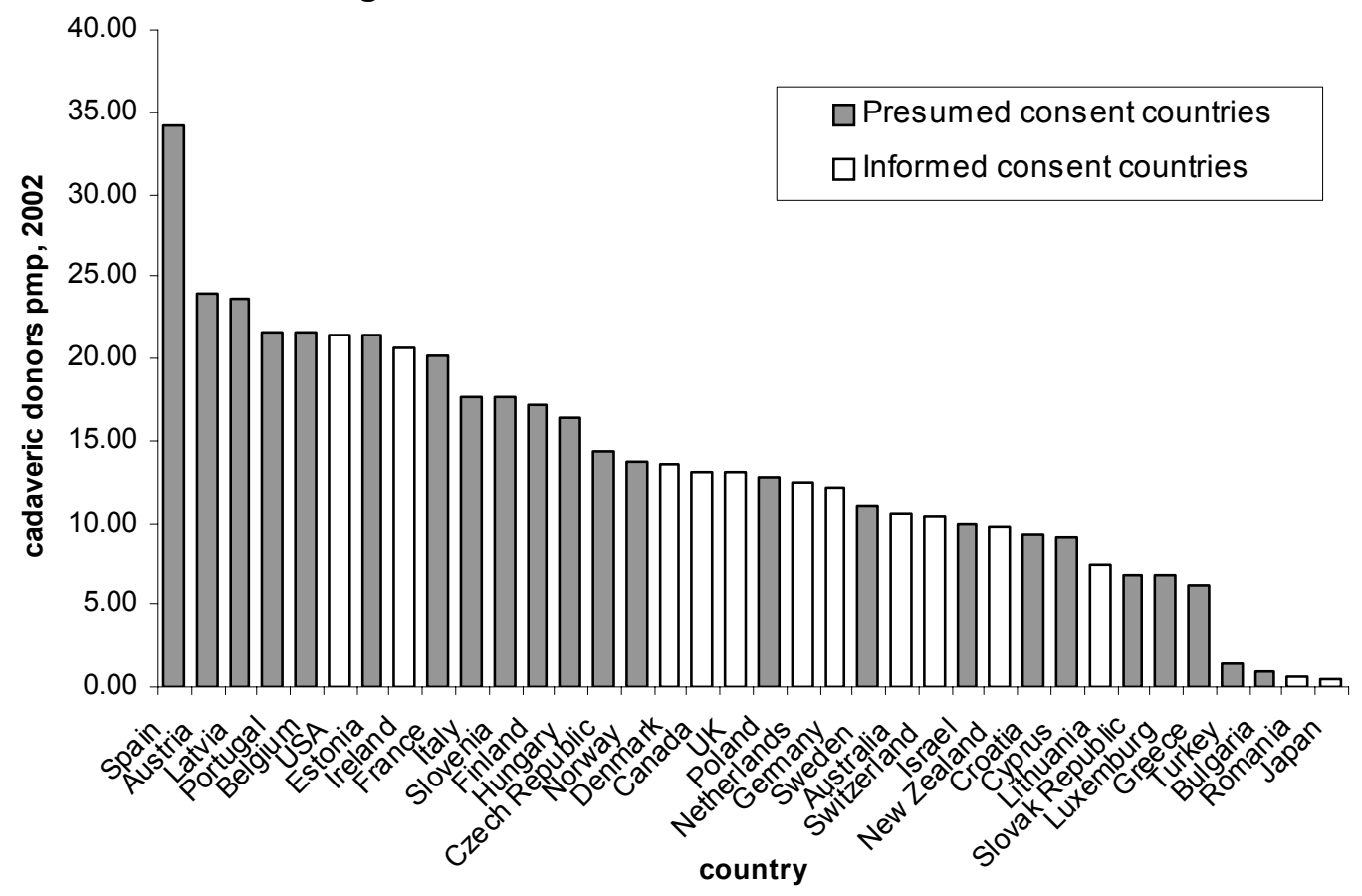


Table I - Descriptive Statistics

(Means and Standard Deviations)

\begin{tabular}{|c|c|c|c|c|}
\hline & $\begin{array}{c}\mathbf{( 1 )} \\
\text { Entire Sample }\end{array}$ & $\begin{array}{c}\mathbf{( 2 )} \\
\text { Presumed } \\
\text { Consent } \\
\text { Countries } \\
\end{array}$ & $\begin{array}{c}\mathbf{( 3 )} \\
\text { Informed } \\
\text { Consent } \\
\text { Countries } \\
\end{array}$ & $\begin{array}{c}\text { (2)-(3) } \\
\text { Difference } \\
\text { (s.e.) }\end{array}$ \\
\hline Presumed consent country & $\begin{array}{c}.5634 \\
{[.4971]}\end{array}$ & & & \\
\hline $\begin{array}{l}\text { Cadaveric donors (per } \\
\text { million population) }\end{array}$ & $\begin{array}{l}15.93 \\
{[5.34]}\end{array}$ & $\begin{array}{l}17.29 \\
{[6.01]}\end{array}$ & $\begin{array}{l}14.19 \\
{[3.72]}\end{array}$ & $\begin{array}{c}3.10 \\
(1.99)\end{array}$ \\
\hline $\begin{array}{l}\text { GDP per capita (constant } \\
1995 \text { USD) }\end{array}$ & $\begin{array}{l}22,310 \\
{[9,780]}\end{array}$ & $\begin{array}{c}19,879 \\
{[11,241]}\end{array}$ & $\begin{array}{l}25,576 \\
{[6,161]}\end{array}$ & $\begin{array}{l}-5,697 \\
(3,731)\end{array}$ \\
\hline $\begin{array}{l}\text { Health expenditures per } \\
\text { capita (constant } 1995 \text { USD) }\end{array}$ & $\begin{array}{l}1,925 \\
{[971]}\end{array}$ & $\begin{array}{l}1,634 \\
{[946]}\end{array}$ & $\begin{array}{l}2,285 \\
{[880]}\end{array}$ & $\begin{array}{l}-651 \\
(399)\end{array}$ \\
\hline Catholic country & $\begin{array}{c}.4439 \\
{[.4981]}\end{array}$ & $\begin{array}{l}.7000 \\
{[.4602]}\end{array}$ & $\begin{array}{l}.1075 \\
{[.3114]}\end{array}$ & $\begin{array}{l}.5925^{* *} \\
(.1663)\end{array}$ \\
\hline Common law & $\begin{array}{c}.2804 \\
{[.4502]}\end{array}$ & $\begin{array}{c}0 \\
{[0]}\end{array}$ & $\begin{array}{c}.6452 \\
{[.4811]}\end{array}$ & $\begin{array}{l}-.6452^{* *} \\
(.1576)\end{array}$ \\
\hline $\begin{array}{l}\text { MVA \& CVD deaths (per } \\
\text { thousand population) }\end{array}$ & $\begin{array}{l}1.2227 \\
{[.4540]}\end{array}$ & $\begin{array}{l}1.4156 \\
{[.4570]}\end{array}$ & $\begin{array}{l}.9518 \\
{[.2217]}\end{array}$ & $\begin{array}{l}.4638^{* *} \\
(.1523)\end{array}$ \\
\hline Number of countries & 22 & 13 & 10 & \\
\hline Number of observations & 213 & 120 & 93 & \\
\hline $\begin{array}{l}\text { Notes: Standard deviations in br } \\
\text { countries with informed and pre } \\
\text { because one of the countries in } t \\
* \text { indicates statistical significanc } \\
* * \text { indicates statistical significan }\end{array}$ & $\begin{array}{l}\text { ets. Standard e } \\
\text { hed consent lay } \\
\text { ample (Sweden } \\
\text { the } 10 \% \text { level. } \\
\text { the } 5 \% \text { level. }\end{array}$ & $\begin{array}{l}\text { n parenthes } \\
\text { not sum to } \\
\text { nged legisla }\end{array}$ & $\begin{array}{l}\text { ustered by c } \\
\text { number of } \\
\text { ng the samp }\end{array}$ & $\begin{array}{l}\text { The numbe } \\
\text { s in the san } \\
\text { d. }\end{array}$ \\
\hline
\end{tabular}




\section{Table II - The Effect of Presumed Consent Legislation on Cadaveric Organ Donation}

(Pooled OLS, 1993-2002)

Dependent variable: Natural logarithm of cadaveric donors per million population

\begin{tabular}{|c|c|c|c|c|c|c|c|c|}
\hline & (1) & (2) & (3) & (4) & (5) & (6) & (7) & (8) \\
\hline \multicolumn{9}{|l|}{ Legislation: } \\
\hline Presumed consent & $\begin{array}{l}.1559 \\
(.1352)\end{array}$ & $\begin{array}{l}.1027 \\
(.1316)\end{array}$ & $\begin{array}{l}.2615^{* *} \\
(.1206)\end{array}$ & $\begin{array}{l}.2577^{* *} \\
(.1233)\end{array}$ & $\begin{array}{l}.2839^{* *} \\
(.1294)\end{array}$ & $\begin{array}{l}.2562^{*} \\
(.1386)\end{array}$ & $\begin{array}{l}.3111^{* *} \\
(.1238)\end{array}$ & $\begin{array}{l}.2493^{* *} \\
(.1164)\end{array}$ \\
\hline \multicolumn{9}{|l|}{ Wealth \& health expenditures: } \\
\hline Log GDP per capita & & & $\begin{array}{l}.2191^{*} \\
(.1205)\end{array}$ & & $\begin{array}{l}.2561^{*} \\
(.1374)\end{array}$ & $\begin{array}{l}.3138^{* *} \\
(.1448)\end{array}$ & $\begin{array}{l}.3032^{* *} \\
(.1309)\end{array}$ & $\begin{array}{l}.3145^{* *} \\
(.1181)\end{array}$ \\
\hline $\begin{array}{l}\text { Log of health } \\
\text { expenditures per capita }\end{array}$ & & & & $\begin{array}{l}.2061^{*} \\
(.1175)\end{array}$ & & & & \\
\hline \multicolumn{9}{|l|}{ Religious beliefs: } \\
\hline Catholic country & & & & & $\begin{array}{l}.1705 \\
(.1717)\end{array}$ & $\begin{array}{l}.0913 \\
(.1846)\end{array}$ & & \\
\hline \multicolumn{9}{|l|}{ Legislative system: } \\
\hline Common law & & & & & $\begin{array}{c}.1636 \\
(.1084)\end{array}$ & $\begin{array}{l}.3109^{*} \\
(.1609)\end{array}$ & $\begin{array}{l}.3233^{*} \\
(.1668)\end{array}$ & $\begin{array}{l}.3460^{* *} \\
(.1643)\end{array}$ \\
\hline \multicolumn{9}{|l|}{ Potential donors: } \\
\hline $\begin{array}{l}\text { Log of MVA \& CVD } \\
\text { deaths (per } 1000 \text { pop.) }\end{array}$ & & & & & & $\begin{array}{l}.4090^{*} \\
(.2282)\end{array}$ & $\begin{array}{l}.4104^{*} \\
(.2244)\end{array}$ & $\begin{array}{l}.4863^{* *} \\
(.1938)\end{array}$ \\
\hline Include Spain & yes & no & yes & yes & yes & yes & yes & no \\
\hline $\begin{array}{c}\text { Specification test } \\
(p \text {-value })\end{array}$ & & & .9504 & .3876 & .9074 & .2230 & .2340 & .3863 \\
\hline$R$-squared & .0587 & .0342 & .2111 & .2124 & .2754 & .3216 & .3111 & .3636 \\
\hline Number of observations & 213 & 203 & 213 & 186 & 213 & 146 & 146 & 140 \\
\hline
\end{tabular}

Notes: The dependent variable is the natural logarithm of cadaveric donation rates, per million population per year. Standard errors (in parentheses) are robust to arbitrary heteroskedasticity and autocorrelation within-country. All specifications include year fixed-effects. The table reports p-values for the null hypothesis of absence of correlated fixed effects.

$*$ indicates statistical significance at the $10 \%$ level.

$* *$ indicates statistical significance at the $5 \%$ level. 


\section{Table III - Presumed Consent and Social Preferences}

(Pooled OLS, 1993-2002)

\begin{tabular}{|c|c|c|c|c|}
\hline & \multicolumn{2}{|c|}{$\begin{array}{l}\text { Dependent variable: } \\
\text { Natural log of cadaveric donors pmp }\end{array}$} & \multicolumn{2}{|c|}{$\begin{array}{l}\text { Dependent variable: } \\
\text { Presumed consent country }\end{array}$} \\
\hline & (1) & (2) & (3) & (4) \\
\hline \multicolumn{5}{|c|}{ Variables from Table II, columns (6) and (7): } \\
\hline Presumed consent & $\begin{array}{l}.2940^{* *} \\
(.1334)\end{array}$ & $\begin{array}{l}.3613^{* *} \\
(.1158)\end{array}$ & & \\
\hline Log GDP per capita & $\begin{array}{l}.2121 \\
(.1558)\end{array}$ & $\begin{array}{l}.2182 \\
(.1479)\end{array}$ & $\begin{array}{l}-.0551 \\
(.1070)\end{array}$ & $\begin{array}{l}-.0488 \\
(.0810)\end{array}$ \\
\hline Catholic country & $\begin{array}{l}.1328 \\
(.1589)\end{array}$ & & $\begin{array}{l}.2947^{*} \\
(.1524)\end{array}$ & \\
\hline Common law & $\begin{array}{l}.4175^{* *} \\
(.1805)\end{array}$ & $\begin{array}{l}.4265^{* *} \\
(.1862)\end{array}$ & $\begin{array}{l}-.6032^{* *} \\
(.1738)\end{array}$ & $\begin{array}{l}-.6856^{* *} \\
(.1558)\end{array}$ \\
\hline $\begin{array}{l}\text { Log of MVA \& CVD } \\
\text { deaths (per } 1000 \text { pop.) }\end{array}$ & $\begin{array}{l}.2740 \\
(.2571)\end{array}$ & $\begin{array}{l}.2975 \\
(.2542)\end{array}$ & $\begin{array}{l}.1936 \\
(.2028)\end{array}$ & $\begin{array}{l}.2890 \\
(.2329)\end{array}$ \\
\hline \multicolumn{5}{|l|}{ Social preferences: } \\
\hline $\begin{array}{l}\text { Log of blood donations } \\
\text { (per } 1000 \text { pop.) }\end{array}$ & $\begin{array}{l}.4374^{*} \\
(.2500)\end{array}$ & $\begin{array}{l}.3459 \\
(.2770)\end{array}$ & $\begin{array}{l}-.1726 \\
(.3657)\end{array}$ & $\begin{array}{l}-.4417 \\
(.3605)\end{array}$ \\
\hline$R$-squared & .3705 & .3494 & 6497 & .5881 \\
\hline
\end{tabular}

Notes: All specifications include year fixed-effects. Standard errors (in parentheses) are clustered at the country level. The number of observations in all specifications is 139 .

* indicates statistical significance at the $10 \%$ level.

** indicates statistical significance at the $5 \%$ level. 


\section{Table IV - Organ Shortage and Potential Increase in Transplantation}

\begin{tabular}{|c|c|c|c|c|c|c|}
\hline \multirow[b]{2}{*}{ year } & \multicolumn{3}{|c|}{ USA } & \multicolumn{3}{|c|}{ UK } \\
\hline & $\begin{array}{c}25 \%, 30 \%] \\
\text { Increase in } \\
\text { Cadaveric } \\
\text { Transplantation } \\
\text { (1) }\end{array}$ & $\begin{array}{l}\text { Change in } \\
\text { waiting list } \\
\text { from } \\
\text { previous year } \\
\text { (2) }\end{array}$ & $\begin{array}{c}\text { Deaths on } \\
\text { waiting list }\end{array}$ & $\begin{array}{c}{[25 \%, 30 \%]} \\
\text { Increase in } \\
\text { Cadaveric } \\
\text { Transplantation } \\
\text { (4) }\end{array}$ & $\begin{array}{l}\text { Change in } \\
\text { waiting list } \\
\text { from } \\
\text { previous year } \\
\text { (5) }\end{array}$ & $\begin{array}{c}\text { Deaths on } \\
\text { waiting list }\end{array}$ \\
\hline 1994 & & & & {$[668,802]$} & 221 & 513 \\
\hline 1995 & {$[3,947,4,736]$} & 5,969 & 3,514 & {$[695,834]$} & 372 & 533 \\
\hline 1996 & {$[3,949,4,738]$} & 6,067 & 4,015 & {$[645,773]$} & 275 & 569 \\
\hline 1997 & {$[4,011,4,814]$} & 6,230 & 4,498 & {$[644,773]$} & 184 & 555 \\
\hline 1998 & {$[4,191,5,030]$} & 6,858 & 5,192 & {$[597,716]$} & 45 & 578 \\
\hline 1999 & {$[4,203,5,043]$} & 5,888 & 6,516 & {$[597,716]$} & 169 & 545 \\
\hline 2000 & {$[4,270,5,124]$} & 6,703 & 6,144 & {$[584,700]$} & 103 & 494 \\
\hline 2001 & {$[4,340,5,208]$} & 5,580 & 6,665 & {$[585,702]$} & 63 & 433 \\
\hline 2002 & {$[4,484,5,380]$} & 2,163 & 6,679 & & & \\
\hline
\end{tabular}

Notes: Columns (1) and (4) show 25\% and 30\% percentages of cadaveric transplantations for each particular year and for the U.S. and the U.K., respectively. Columns (2) and (5) show the yearly change in the number of patients on organs waiting lists for the U.S. and the U.K., respectively. Columns (3) and (6) show the number of deaths on the organs waiting lists for the U.S. and the U.K., respectively. 